\title{
Productivity, Profitability and Economic Viability of a Diversified Farm in Faridkot District of Punjab, India
}

\author{
Gurdarshan Singh*, B.S. Dhillon and J.K. Grover \\ Krishi Vigyan Kendra,Model Agricultural farm, circular Road Faridkot, Punjab, India \\ *Corresponding author
}

\begin{tabular}{|c|c|}
\hline & A B S T R A C T \\
\hline & $\begin{array}{l}\text { Rice-wheat is a major cropping system prominent on } 2.5 \text { million hectares in Punjab. } \\
\text { Irrigation is commonly used to stabilize the productivity of this system using surface canal } \\
\text { and sub-soil tube well water. Judicious use of water and land resources has been a major } \\
\text { challenge for agriculture and it is imperative to use these scarce resources efficiently. This }\end{array}$ \\
\hline Keywords & paper describes various alternative cropping systems being adopted by a progressive \\
\hline $\begin{array}{l}\text { Cropping system, } \\
\text { Horticultural } \\
\text { crops, REY, Rice } \\
\text { - Wheat. }\end{array}$ & $\begin{array}{l}\text { farmer to attain the goal of raising productivity and meeting food security needs along with } \\
\text { efficient use of natural resources including water, providing environmental benefits and } \\
\text { improving the rural livelihood of farmers. The results of investigations reveal that } \\
\text { vegetable based cropping systems and horticultural crops gave higher rice equivalent yield }\end{array}$ \\
\hline Article Info & profitability of various cropping systems indicated the highest net returns under rainy \\
\hline $\begin{array}{l}\text { Accepted: } \\
\text { 29 May } 2017 \\
\text { Available Online: } \\
\text { 10 June } 2017\end{array}$ & $\begin{array}{l}\text { season bottle gourd-summer squash cropping system (Rs } 6,06,075 / \mathrm{ha} \text { ), which was } \\
\text { followed by rainy season bottle gourd-capsicum and rainy season bottle gourd-tomato } \\
\text { cropping system. Rice-wheat recoded the lowest net returns (Rs.1, 29,963/ha). The B: C } \\
\text { ratio of different cropping systems varied from } 2.87 \text { to } 4.84 \text { and predominant rice-wheat }\end{array}$ \\
\hline & $\begin{array}{l}\text { horticultural based cropping systems are biologically efficient and highly profitable, } \\
\text { however; Punjab farmers' still prefer rice-wheat sequence due to their better stability and } \\
\text { assured marketing. }\end{array}$ \\
\hline
\end{tabular}

\section{Introduction}

During the 1950s and early 1960s, South Asia suffered frequent and severe food shortages. Beginning in the late 1960s, however, production of rice and wheat increased dramatically throughout the region due to 'Green Revolution,' spurred by new high yielding dwarf wheat and rice varieties, a favorable resource base, rapid expansion of fertilization and irrigation facilities and an extremely supportive policy environment. The Green revolution greatly reduced the incidence of hunger and starvation through rapid growth in agricultural production, particularly in India's rice-wheat cropping systems.

Presently, rice-wheat system provides the staple grain supply for about $8 \%$ of the world's population, making this system critically important for global food security (Ladha et al., 2003, Timsina and Connor 2001). In Punjab, rice-wheat is the most predominant cropping system adopted on an area of $2.53 \mathrm{~m}$ ha. 
Its cultivation has been extended to the nonconventional area because of its better adaptation, favorable government policies and free electricity for tube wells. Farmers are getting productivity from rice based cropping systems at the cost of over exploitation of natural resources. Continuous rice-wheat cultivation has led to the buildup of pests and diseases and has also led to land degradation as continuous puddling destroys the soil structure that takes long time to come into normal condition. The ecological intensification of agricultural systems is aimed at satisfying the anticipated increase in demand for agricultural products while meeting acceptable standards of environmental quality (Cassman 1999). Higher productivity with sustainability remains the major concern of any crop planning. Any cropping system which requires less input but has higher productivity is considered to be the efficient. Hence, in view of concerns regarding degradation of natural resources and new policies of open economy, there is a dire need for diversification of farming by shifting considerable area towards other crops/ cropping system like vegetables and fruit crops.

Punjab is a tiny state of India having geographical area of 50 lac ha, out of which 48.6 lac ha is cultivable land. However, the situation is more alarming due to the fact that more than 28.9 lac ha is under paddy cultivation and a sizable area of only 2.80 lac ha is under orchard and vegetable crops (Anonymous 2014, 2015). Majority of the farmers are engaged in rice- wheat cropping system with some exceptions. One such exception is S. Amarjit Singh Dhillon from village Bargari, District Faridkot, Punjab. His farm is a picture- perfect highly diversified farm that boosts of variety of crops including wheat, paddy and some horticultural and vegetable crops. Adoption of horticultural and vegetable crops besides giving higher income has the added advantage of limited water requirement and potential of employment generations throughout the year. In this study, we have made an attempt to evaluate the performance of different cropping systems using various indicators of system efficiency.

\section{Materials and Methods}

The present studies were undertaken at the diversified farm of S. Amarjit Singh Dhillon from village Bargari, district Faridkot, situated at $30^{\circ} 31^{\prime} \mathrm{N}$ latitude and $74^{\circ} 55^{\prime} \mathrm{E}$ longitude with a height of 210 meter above the mean sea level in South-western arid zone of Punjab. Out of an operational land holding of 10.0 hectares, $50 \%$ of the area is under horticultural crops. He has installed drip irrigation system throughout his farm and harnesses the benefits of solar energy to uplift water from storage tank. He raises rainy season bottle gourd under bower and summer season bottle gourd, summer squash, tomato and capsicum under low tunnel. The sowing and harvesting of various crop grown by him is depicted in table 1 .

A questionnaire was prepared to gather information regarding the yield and gross returns of different crops as well as income and expenditure incurred thereof at the farm of Amarjit Singh Dhillon. For valid comparison of different cropping systems, the yield of crops was converted into rice equivalent yield by considering the price of produce. System productivity (yield per unit area per unit time) was calculated by dividing rice equivalent yield by 365 . Relative production efficiency (RPE) of different cropping systems in relation to the predominant (rice-wheat) cropping system was calculated as under:

RPE $(\%)=$ EYD-EYE $\times 100 / E Y E$ where EYE denotes rice equivalent yield under 
predominant (rice-wheat cropping system) and EYD denotes rice equivalent yield under diversified cropping systems. Net returns per ha were calculated by subtracting cost of cultivation (as per budget ledger of farmer) from gross returns of a particular crop in cropping system. The benefit cost ratio (B: C ratio) for different cropping systems was calculated by dividing the gross returns by cost of cultivation in the system.

\section{Results and Discussion}

The data in table 2 revealed that all the alternative cropping systems/ crops out yielded rice-wheat cropping system. It is further evident that vegetable based cropping system (rainy season bottle gourd trained on bower system-capsicum/tomato/summer squash) gave 503.9, 456.2 and 552.8 $\mathrm{q} / \mathrm{ha} /$ annum rice equivalent yield, respectively, against $129.5 \mathrm{q} / \mathrm{ha} / \mathrm{annum}$ in rice-wheat cropping system. Likewise, summer season bottle gourd as intercrop in newly planted kinnow orchard, sole crop of guava, grapes and kinnow (14 years each) also resulted in higher rice equivalent yield of 162.9, 318.6, 233.7 and 306.2 q /ha/annum, respectively. The higher rice equivalent yield in horticultural crops/ cropping pattern can be ascribed to the higher yield of horticultural crops. Similar trend was also observed for system productivity. Gangwar et al., (2006) also reported higher system productivity under horticultural crops. The data on relative production efficiency (RPE) of various cropping systems in comparison to predominant rice-wheat cropping system also indicated the highest values under rainy season bottle gourd-capsicum/tomato/summer squash cropping system, which recorded the relative production efficiency of 289.1, 252.3 and $326.9 \%$ respectively. Similarly, summer season bottle gourd as intercrop in newly planted kinnow orchard, sole crop of guava, grapes and kinnow (14 years each) also resulted in higher RPE.

Table.1 Sowing and harvesting period of different crops and area under different crops

\begin{tabular}{|c|c|c|c|c|}
\hline $\begin{array}{l}\text { S. } \\
\text { No. }\end{array}$ & Crop/fruit/vegetable & $\begin{array}{l}\text { Sowing/ transplanting } \\
\text { time }\end{array}$ & Crop over by & Area (ha) \\
\hline 1 & Guava & \multirow{3}{*}{\multicolumn{2}{|c|}{ Perennial crops }} & 0.8 \\
\hline 2 & Grapes & & & 0.6 \\
\hline 3 & Kinnow & & & 1.8 \\
\hline 3 & $\begin{array}{l}\text { Bottle gourd (under } \\
\text { bower) }\end{array}$ & $\begin{array}{l}\text { Rainy season crop : Last } \\
\text { week of May to } 1^{\text {st }} \text { week } \\
\text { of June }\end{array}$ & $\begin{array}{l}2^{\text {nd }} \quad \text { week } \quad \text { of } \\
\text { November }\end{array}$ & 1.2 \\
\hline & Bottle gourd & $\begin{array}{l}\text { Summer season crop : } \\
\text { Last week of November }\end{array}$ & $2^{\text {nd }}$ fortnight of May & 0.8 \\
\hline 4 & Capsicum & $\begin{array}{l}2^{\text {nd }} \quad \text { fortnight } \\
\text { November }\end{array}$ & Last week of May & 0.2 \\
\hline 5 & Tomato & $1^{\text {st }}$ week of December & Last week of May & 0.2 \\
\hline 6 & Summer squash & Last week of November & First week of April & 0.8 \\
\hline 7 & Paddy & $15^{\text {th }}$ to $20^{\text {th }}$ June & $\begin{array}{l}1^{\text {st }} \text { fortnight of } \\
\text { October }\end{array}$ & 4.8 \\
\hline 8 & Wheat & $\begin{array}{l}1^{\text {st }} \text { fortnight } \\
\text { November }\end{array}$ & $\begin{array}{l}2^{\text {nd }} \text { fortnight of } \\
\text { April }\end{array}$ & 4.8 \\
\hline
\end{tabular}


Table.2 Yield of crops in system and indicators of system efficiency under various cropping systems

\begin{tabular}{|c|c|c|c|c|c|}
\hline \multirow[t]{2}{*}{ Crops/ cropping system } & \multicolumn{2}{|c|}{ Yield (q/ha) } & \multirow{2}{*}{$\begin{array}{c}\text { Rice } \\
\text { equivalent } \\
\text { yield (q/ha) }\end{array}$} & \multirow{2}{*}{$\begin{array}{c}\text { System } \\
\text { Productivity } \\
\text { (Kg/ha/day) }\end{array}$} & \multirow{2}{*}{$\begin{array}{c}\text { Relative } \\
\text { Production } \\
\text { Efficiency }(\%)\end{array}$} \\
\hline & 1 & 2 & & & \\
\hline Rice-Wheat & 76.25 & 50.75 & 129.5 & 35.5 & - \\
\hline $\begin{array}{c}\text { Rainy season bottle gourd } \\
\text { trained on bower system- } \\
\text { capsicum }\end{array}$ & 318.75 & 252.50 & 503.9 & 138.1 & 289.1 \\
\hline $\begin{array}{c}\text { Rainy season bottle gourd } \\
\text { trained on bower system- } \\
\text { Tomato }\end{array}$ & 312.5 & 321.30 & 456.2 & 125.0 & 252.3 \\
\hline $\begin{array}{c}\text { Rainy season bottle gourd } \\
\text { trained on bower system- } \\
\text { summer squash }\end{array}$ & 317.5 & 250.25 & 552.8 & 151.5 & 326.9 \\
\hline $\begin{array}{l}\text { Summer season bottle gourd } \\
\text { as intercrop in newly } \\
\text { planted kinnow orchard }\end{array}$ & 337.5 & - & 162.9 & 44.64 & 25.8 \\
\hline Guava (Age 14 yr) & \multicolumn{2}{|c|}{385} & 318.6 & 87.3 & 146.0 \\
\hline Grape (Age 8 yr) & \multicolumn{2}{|c|}{242} & 233.7 & 64.03 & 80.5 \\
\hline Kinnow (Age 8 yr) & \multicolumn{2}{|c|}{444} & 306.2 & 83.9 & 136.4 \\
\hline
\end{tabular}

Table.3 Profitability and economic viability of various crops/ cropping systems

\begin{tabular}{|l|c|c|c|c|c|}
\hline Cropping system & $\begin{array}{l}\text { Gross } \\
\text { Returns } \\
\text { (Rs/ha) }\end{array}$ & $\begin{array}{l}\text { Variable } \\
\text { Cost } \\
\text { (Rs/ha) }\end{array}$ & $\begin{array}{l}\text { Net returns } \\
\text { (Rs/ha) }\end{array}$ & $\begin{array}{l}\text { Profitability } \\
\text { (Rs/ha/day) }\end{array}$ & B:C ratio \\
\hline Rice-Wheat & $1,87,956$ & 57,993 & $1,29,963$ & 356 & 3.24 \\
\hline $\begin{array}{l}\text { Rainy season bottle gourd trained on } \\
\text { bower system-capsicum }\end{array}$ & $7,30,625$ & $1,97,750$ & $5,32,875$ & 1460 & 3.69 \\
\hline $\begin{array}{l}\text { Rainy season bottle gourd trained on } \\
\text { bower system-Tomato }\end{array}$ & $6,61,530$ & $1,91,750$ & $4,69,780$ & 1287 & 3.45 \\
\hline $\begin{array}{l}\text { Rainy season bottle gourd trained on } \\
\text { bower system-summer squash }\end{array}$ & $8,01,575$ & $1,95,500$ & $6,06,075$ & 1660 & 4.10 \\
\hline $\begin{array}{l}\text { Summer season bottle gourd as } \\
\text { intercrop in newly planted kinnow } \\
\text { orchard }\end{array}$ & $2,36,250$ & 70,500 & $1,65,750$ & 454 & 3.35 \\
\hline Guava (Age 14 yr) & & & & & \\
\hline Grape (Age 8 yr) & $4,62,000$ & 95,500 & $3,66,500$ & 1004 & 4.84 \\
\hline Kinnow (Age 8 yr) & $3,38,800$ & $1,18,000$ & $2,20,800$ & 605 & 2.87 \\
\hline
\end{tabular}


The data on economic viability and profitability of various cropping systems indicated the highest net returns per ha under rainy season bottle gourd-summer squash cropping system (Rs 6, 06,075/ha) followed by rainy season bottle gourd-capsicum and rainy season bottle gourd-tomato cropping system. Rice-wheat recorded the lowest net returns (Rs. 1, 29,963/ha) and profitability (Rs 356/ha/day). The B: $\mathrm{C}$ ratio of different cropping systems varied from 2.87 to 4.84 and predominant rice-wheat cropping system recorded $\mathrm{B}: \mathrm{C}$ ratio of 3.24 (Table 3 ). Dhillon et al., (2012) also reported higher profitability of cropping systems alternative to rice-wheat. It may be concluded that the vegetable and horticultural crops are biologically efficient, highly profitable crop sequences, however; the Punjab farmers' still prefer rice-wheat sequence due to their better stability and assured marketing.

\section{References}

Anonymous (2014) Package of practices for cultivation of fruits. $P p .1$.

Anonymous (2015) Package of practices for cultivation of vegetables. $P$ p. 1.

Anonymous (2015) Package of practices for cultivation of Kharif crops. Pp. 1.

Anonymous (2015) Package of practices for cultivation of Rabi crops. Pp. 1.

Cassman K G (1999) Ecological intensification of cereal production system: Soil quality and precision agriculture. Proceedings of National Academy of Science (USA). Pp: 5952-59

Dhillon B S, Walia S S, Singh D, Singh K B and Gill N S (2012) Productivity and economic viability of prevailing cropping systems in Moga district of Punjab (India). Proceedings of $3^{\text {rd }}$ International Agronomy Congress on "Agriculture Diversification, Climate Change Management and Livelihoods" held at 26-30 November 2012 at IARI, New Delhi. Pp 1025

Gangwar,B, Katyal V and Anand K V (2006) Stability and efficiency of different cropping systems in Western Himalayas. Indian J Agric Sci 76 (2): 135-39

Ladha J K, Pathak H, Tirol Parde A, Dawe D and Gupta R K (2003) Productivity trends of intensive rice-wheat cropping system of Asia. In improving the productivity and sustainability of ricewheat system: Issues and impacts. Ed. J $\mathrm{K}$ Ladha et al., pp: 45-76. American Society of Agronomy. Special Publication. 65 Madison, Wisconsin.

Timsina J and Connor D J (2001). Productivity and management of ricewheat cropping systems: Issues and challenges. Field crop Res. 69: 93-132.

\section{How to cite this article:}

Gurdarshan Singh, B.S. Dhillon and Grover, J.K. 2017. Productivity, Profitability and Economic Viability of a Diversified Farm in Faridkot District of Punjab, India. Int.J.Curr.Microbiol.App.Sci. 6(6): 2463-2467. doi: https://doi.org/10.20546/ijcmas.2017.606.292 